\title{
PENGARUH INDIVIDU, DUKUNGAN KELUARGA DAN SOSIAL BUDAYA TERHADAP KONSUMSI MAKANAN IBU MUDA MENYUSUI (Studi Kasus Di Desa Sofyan Kecamatan Simeulue Timur Kabupaten Simeulue) (The Influence of Individuals, Family Support and Social Culture toward Food Consumption of Young Breastfeeding Mother (Case Study in Sofyan Village, Simeulue Timur Districts, Simeulue District)
}

\author{
T.M. Rafsanjani ${ }^{*}$ \\ ${ }^{1}$ Fakultas Kesehatan Masyarakat, Universitas Serambi Mekkah, Jl. Teuku Nyak Arief, No. 206. Simpang Mesra \\ Jeulingke, Syiah Kuala, Kota Banda Aceh. Email: tmrafsanjani@serambimekkah.ac.id
}

\begin{abstract}
ABSTRAK
Makanan yang diberikan kepada ibu menyusui harus mengandung cukup kalori (energi) guna mengganti energi yang dikeluarkan maupun yang dibutuhkan untuk menghasilkan ASI. Berbagai faktor yang mempengaruhi gizi ibu pada masa menyusui, adalah kurangnya pengetahuan ibu, kurangnya rasa percaya diri ibu/sikap, serta kurangnya dukungan keluarga dan lingkungan. Penelitian ini bersifat survey analitik, pendekatan cross sectional dengan responden penelitian 34 orang yang merupakan total dari populasi. Analisis data dilakukan dengan analisis univariat dan bivariat dengan tujuan menguji hipotesis, dengan menggunakan aplikasi komputer SPSS versi 17, dan digunakan uji Chi-Square Tets $\left(x^{2}\right)$, dengan kategori bermakna jika p value < 0,05. Hasil penelitian menunjukkan bahwa ada pengaruh pemahaman individu terhadap konsumsi makanan ibu muda menyusui dengan $p=0,003$, ada pengaruh dukungan keluarga terhadap konsumsi makanan ibu muda menyusui dengan nilai $p=0,028$, dan ada pengaruh sosial budaya terhadap konsumsi makanan ibu muda menyusui dengan nilai $p=0,027$. Dapat disimpulkan bahwa terdapat pengaruh antara pemahaman individu, dukungan keluarga dan sosial budaya terhadap konsumsi makanan ibu muda menyusui. Diharapkan kepada Puskesmas, bidan dan masyarakat agar dapat meningkatkan pemahaman individu ibu muda menyusui dan masyarakat tentang kebutuhan nutrisi pada masa menyusui melalui .
\end{abstract}

Kata kunci : ASI, budaya, gizi seimbang, menyusui

\begin{abstract}
Food that given to the breastfeeding mother should contains sufficient calories (energy) to replace the energy released as well as the energy needed to produce breast milk. Various factors that influence mother's nutrient in breastfeeding period are lack of
\end{abstract}

knowledge, lack of confident/attitude, also lack of family support and environment. This research used analytical survey with cross sectional study approach. The respondents of this research were 34 mothers that also the total of population. Data analysis was performed in univariate and bivariate analysis with the purpose of testing the hypothesis. Then, the method used was Chi-Square Test (x2) and used the SPSS $17^{\text {th }}$ version. The result would considered significant if $p$ value $<0,05$. The result of this study shows that there were influence of individual understanding toward consumption of young breastfeeding mother with $p$ value 0,003. There were influence of family support toward consumption of young breastfeeding mother with $p$ value 0,028. Then, there were influence of social culture toward consumption of young breastfeeding mother with $p$ value 0,027. It can be concluded that there was an influence between individual understanding, family support and social culture toward food consumption of young breastfeeding mothers. Midwives and the community are expected to improve the understanding of individual breastfeeding young mothers and the community about nutritional needs during breastfeeding in various ways, including counseling and mentoring.

Keywords : Balanced nutrition, breastfeeding, breast milk, culture

\section{PENDAHULUAN}

Menyusui adalah proses pemberian air susu ibu (ASI) kepada bayi sejak lahir sampai berusia 2 tahun. Jika bayi diberikan ASI saja sampai usia enam bulan tanpa menambahkan dan mengganti dengan makanan atau minuman lainnya merupakan proses menyusui eksklusif. ${ }^{1}$

${ }^{*}$ Penulis untuk korespondensi: tmrafsanjani@serambimekkah.ac.id 
Air Susu Ibu menjadi salah satu program World Health Organization (WHO) dan Pemerintah RI yang gencar dikemukakan di sektor kesehatan untuk mengurangi morbiditas dan mortalitas anak. ASI adalah sumber nutrisi yang primer bagi anak sejak dilahirkan sampai ia mampu mencernakan asupan lain setelah usia enam bulan. Lemak, protein, karbohidrat, vitamin, mineral, enzim, dan hormon yang terdapat dalam ASI tidak dapat digantikan oleh susu buatan industri. ASI mengandung zat-zat kekebalan yang melindungi anak dari infeksi dan penyakit kronis, serta mengurangi kemungkinan menderita gangguan kesehatan di kemudian hari seperti obesitas, diabetes, dan asma. ${ }^{2}$

Jumlah produksi ASI bergantung pada besarnya diet ibu selama menyusui, ibu menyusui harus mendapatkan tambahan zat sebesar 800 kkal yang digunakan untuk memproduksi ASI dan untuk aktivitas ibu sendiri. ${ }^{3}$ Pada prinsipnya, makanan yang diberikan kepada ibu menyusui harus mengandung cukup kalori (energi) untuk dapat mengganti energi yang dikeluarkan maupun yang dibutuhkan untuk menghasilkan ASI. Komposisi yang terkandung dalam makanan diusahakan seimbang dan dapat memenuhi kebutuhan nutrisi untuk menjaga keadaan dan berat badan ibu selama menyusui. ${ }^{4}$

Selama pemberian ASI, pihak keluarga, pemerintah daerah dan masyarakat harus mendukung ibu secara penuh dengan penyediaan waktu dan fasilitas khusus. Penyediaan fasilitas khusus dimaksudkan adalah pada lokasi tempat ibu menyusui tersebut bekerja. ${ }^{5}$

Diperhatikan agar dapat menyusui, tubuh disiapkan mulai dari masa kehamilan, payudara membesar, dilanjutkan dengan menyimpan cadangan energi berupa tambahan jaringan lemak, dan volume darah. Pada ibu menyusui, Kebutuhan kalori proposional dengan jumlah air susu ibu yang dihasilkan, dan lebih tinggi dibanding selama hamil $( \pm 500 \mathrm{kkal} / \mathrm{hr}) \times \mathrm{Jumlah}$ produksi ASI yang tergantung pada besarnya cadangan lemak yang tertimbun selama hamil. Untuk menghasilkan $100 \mathrm{cc}$ susu dibutuhkan kalori sekitar $85 \mathrm{kkal}, 850 \mathrm{cc}$ susu $=750 \mathrm{kkal} \mathrm{yg}$ dibutuhkan dari makanan dan cadangan endogen. ${ }^{6}$
Terdapat beberapa faktor yang mempengaruhi gizi ibu pada masa menyusui, diantaranya adalah kurangnya pengetahuan ibu, kurangnya rasa percaya diri ibu/sikap, serta kurangnya dukungan keluarga dan lingkungan pada proses menyusui ibu. ${ }^{3}$ Banyaknya ASI yang akan dihasilkan seorang ibu tidak tergantung pada besarnya payudara, tetapi pada gizi ibu selama hamil dan menyusui, serta cara menyusui, namun tidak sedikit ibu yang belum mengerti dan menganggap remeh hal itu, seharusnya ibu mesti mencari informasi tentang gizi makanan ketika menyusui agar bayi tumbuh sehat, dan saat menyusui ibu memerlukan makanan 1 1/2 kali lebih banyak daripada biasanya, dan minum minimal 8 gelas sehari. ${ }^{7}$ Kurangnya dukungan keluarga menjadi salah satu pembentukkan emosional ibu pada saat menyusui. Dukungan keluarga memiliki empat fungsi dukungan meliputi dukungan informasi, dukungan penilaian, dukungan instrumental, dan dukungan emosi. ${ }^{8}$ Jika ibu mengalami gangguan emosi, maka kondisi itu bisa menganggu proses let down reflex yang mengakibatkan ASI tidak keluar, sehingga bayi tidak mendapat ASI dalam jumlah yang cukup.

Penelitian ini sesuai dengan penelitian tentang gambaran pengetahuan ibu tentang menyusui dan dampaknya terhadap pemberian ASI eksklusif, dimana diperoleh bahwa tingkat pengetahuan ibu yang berkaitan dengan menyusui masih dikatagorikan rendah dan informasi/nasihat yang diberikan tenaga kesehatan terkait menyusui ini juga masih kurang. Hal ini diduga berdampak buruk terhadap buruknya kualitas pemberian asi, yang dibuktikan rendahnya cakupan ASI eksklusif. ${ }^{9}$ Selain itu juga merujuk pada penelitian yang dilakukan terkait hubungan asupan gizi dengan produksi asi pada ibu yang menyusui bayi umur 0-6 bulan di Puskesmas Sewon I Bantul yogyakarta, dengan hasil bahwa ada hubungan antara asupan gizi dengan produksi asi ibu. ${ }^{10}$

Melihat penelitian sebelumnya maka muncul hal yang membedakan antara penelitian ini, yaitu penelitian dilakukan pada spesifik ibu yang masih muda atau anak pertama, dan kajian sosial budaya lebih dominan pada penelitian ini, sehingga memperoleh pengetahun bukan hanya dari aspek indovidu saja tapi juga kearifan lokal masyarakat. 
Desa Sefoyan memiliki penduduk sebanyak 267 orang, dengan jumlah balita sebanyak 56 orang dan jumlah ibu menyusui sebanyak 34 orang. Bayi yang diberikan ASI eksklusif sebanyak 4 orang, dengan jumlah balita gizi kurang sebanyak 10 orang, 1 orang ibu hamil mengalami KEK, dan 3 orang ibu menyusui mengalami status gizi kurang. Berdasarkan studi pendahuluan awal yang peneliti lakukan di Desa Sefoyan Wilayah Kerja Puskesmas Simeulue Timur selama enam hari, diperoleh bahwa hingga saat ini masih banyak ibu-ibu yang belum mengetahui bagaimana pola konsumsi makanan pada masa menyusui, dan dari hasil wawancara dengan 10 orang ibu menyusui, diperoleh bahwa 4 dari 10 orang ibu menyusui tidak memiliki menu khusus pada saat menyusui, mereka hanya makan makanan nasi, sayur dan lauk pauk tanpa memiliki menu seimbang untuk meningkatkan kelancaran ASI. Disisi lain kurangnya dukungan keluarga dalam proses menyusui ibu diakrenakan proses menyusui pada ibu muda, merupakan hal biasa seperti orang tua terdahulu.

Masyarakat Sefoyan memiliki kondisi sosial budaya yang tergolong unik, dimana keberadaan tetua yang masih dominan, menjadi panutan dalam hal mengkonsumsi makanan saat hamil dan saat menyusui, kurang disadari bahwa, asupan makanan yang tidak memenuhi standar gizi yang baik, mengakibatkan kurangnya asupan asi pada bayi, dengan demikian masyarakat akan menganggap bahwa ASI tidak memenuhi kebutuhan si bayi yang pada akhirnya juga mempengaruhi atau mendorong ibu untuk memberikan makanan tambahan pada bayi.

Berdasarkan permasalahan demi permasalahan yang tersebut di atas, maka laik dan menarik untuk dilakukan penelitian dengan tujuan mengetahui pengaruh faktor individu, dukungan keluarga dan sosial budaya terhadap konsumsi makanan ibu muda menyusui di desa Sefoyan Kabupaten Simeulue.

\section{METODE}

Penelitian ini bersifat survey analitik dengan pendekatan cross sectional yaitu variabel-variabel yang termasuk faktor resiko dan diteliti pada waktu yang bersamaan tentang faktor-faktor yang mempengaruhi konsumsi makanan ibu muda menyusui, dengan responden yaitu seluruh ibu menyusui pertama yang memiliki anak usia 0-24 bulan berjumlah 34 orang yang merupakan total populasi.

Penelitian ini dilakukan selama 25 hari di wilayah penelitian dengan menggunakan Alat pengumpulan data adalah kuisioner yang berbentuk pilihan multiple choise dan dhicotomy choise untuk mengukur variabel faktor-faktor yang mempengaruhi konsumsi makanan ibu menyusui.

Analisis data dilakukan dengan univariat dengan tujuan melihat distribusi frekuensi variabel independen dan variabel dependen dan analisis bivariat dengan tujuan menguji hipotesis, dengan menggunakan aplikasi komputer SPSS versi 17, dan untuk menentukan hubungan antara variabel digunakan uji ChiSquare Tes (x2), dengan kategori bermakna jika $p$ value $<0,05$. Data hasil peneilitian disajikan dalam bentuk tabel distribusi frekuensi, tabulasi silang serta dalam bentuk narasi.

\section{HASIL DAN PEMBAHASAN}

\section{Karakteristik Responden}

Penelitian dilakukan pada responden yang memiliki karakteristik sebagai berikut:

\section{Tabel 1. Karakteristik Responden Penelitian}

\begin{tabular}{|c|c|c|}
\hline Karakteristik Responden & $\mathrm{n}$ & $\%$ \\
\hline \multicolumn{3}{|l|}{ Umur } \\
\hline Reproduktif (20-35 Th) & 28 & 82,4 \\
\hline Non Reproduktif (> $35 \mathrm{Th}$ ) & 6 & 17,6 \\
\hline \multicolumn{3}{|l|}{ Pendidikan } \\
\hline Tinggi (D3-S1) & 3 & 8,1 \\
\hline Menengah (SMA/MA) & 21 & 61,8 \\
\hline Dasar (SD-SMP) & 10 & 29,4 \\
\hline \multicolumn{3}{|l|}{ Pekerjaan } \\
\hline PNS & 6 & 17,6 \\
\hline Swasta & 11 & 32,4 \\
\hline Petani & 5 & 14,7 \\
\hline IRT & 12 & 35,3 \\
\hline Jumlah & 34 & 100 \\
\hline
\end{tabular}

Berdasarkan tabel 1, menunjukkan bahwa dari 34 responden yang diteliti, maka diperoleh 
sebanyak 82,4 \% responden dengan umur reproduktif (20 - 35 tahun), dan $61,8 \%$ berpendidikan menengah dan sebanyak $35,3 \%$ berprofesi sebagai Ibu Rumah Tangga.

Penelitian yang dilakukaan pada variabel individu, dukungan keluarga dan sosial budaya masyarakat, memberikan beberapa informasi penting secara tunggal dan murni, yaitu secara kuantitas 79,4\% responden memiliki konsumsi makanan yang cukup, namun secara kualitas yang dinilai dari aspek gizi seimbang, maka dapat disimpulkan bahwa belum memenuhi gizi seimbang.

Secara individu, responden memiliki perhatian dan pemahaman terhadap diri sendiri yang berkaitan dengan pola makan dikategorikan kurang baik sebesar 38,2\%, sedangkan untuk dukungan keluarga dengan indikator yang dilihat adalah motivasi, dan membantu menyediakan makanan bagi ibu muda menyusui, diperoleh sebesar $26,6 \%$ kurang mendukung. Pada variabel sosial budaya diperoleh sebesar 44,1\% dengan kategori sosial budaya kurang baik, hal ini diasumsikan bahwa, segenap kebiasaan masyarakat setempat hampir seutuhnya merujuk pada perilaku orang terdahulu, dan dalam penyediaan makanan hanya diutamakan pada nasi dan ikan, karena wilayah yang dekat dengan laut. Sebagaimana dijelaskan pada tabel 2 berikut:

Tabel 2. Distribusi Frekuensi Variabel Penelitian

\begin{tabular}{lcc}
\hline \multicolumn{1}{c}{ Variabel } & $\mathrm{n}$ & $\%$ \\
\hline Konsumsi Makanan Ibu & & \\
Menyusui & & \\
$\quad$ Cukup & 27 & 79,4 \\
$\quad$ Kurang & 7 & 20,6 \\
Pemahaman Individu & & \\
$\quad$ Baik & 21 & 61,8 \\
$\quad$ Kurang Baik & 13 & 38,2 \\
Dukungan Keluarga & & \\
$\quad$ Mendukung & 27 & 79,4 \\
$\quad$ Kurang Mendukung & 77 & 20,6 \\
Sosial Budaya & & \\
$\quad$ Baik & 19 & 55,9 \\
$\quad$ Kurang Baik & 15 & 44,1 \\
\hline$\quad$ Jumlah & 34 & 100 \\
\hline
\end{tabular}

Selanjutnya berdasarkan hasil analisis secara bivariat ditemukan hasil yang menunjukkan hubungan antara variabel dependen dengn variabel independen, sebagai berikut ini:

Tabel 3. Hasil uji chi square test pada variabel independen terhadap konsumsi makanan ibu menyusui

\begin{tabular}{|c|c|c|c|c|c|c|c|}
\hline \multirow{3}{*}{ Variabel Independen } & \multicolumn{4}{|c|}{$\begin{array}{l}\text { Konsumsi Makanan Ibu } \\
\text { Muda Menyusui }\end{array}$} & \multirow{2}{*}{\multicolumn{2}{|c|}{ Total }} & \multirow{3}{*}{$p$} \\
\hline & \multicolumn{2}{|c|}{ Cukup } & \multicolumn{2}{|c|}{ Kurang } & & & \\
\hline & $\mathrm{n}$ & $\%$ & $\mathrm{n}$ & $\%$ & $\mathrm{n}$ & $\%$ & \\
\hline \multicolumn{8}{|l|}{ Pemahaman Individu } \\
\hline Baik & 19 & 90,5 & 2 & 9,5 & 21 & 100 & \multirow{2}{*}{0,003} \\
\hline Kurang Baik & 6 & 46,2 & 7 & 53,8 & 13 & 100 & \\
\hline \multicolumn{8}{|l|}{ Dukungan Keluarga } \\
\hline Mendukung & 23 & 85,2 & 4 & 14,8 & 27 & 100 & \multirow{2}{*}{0,028} \\
\hline Kurang Mendukung & 2 & 28,6 & 5 & 71,4 & 7 & 100 & \\
\hline \multicolumn{8}{|l|}{ Sosial Budaya } \\
\hline Baik & 16 & 84,2 & 3 & 15,8 & 19 & 100 & \multirow{2}{*}{0,027} \\
\hline Kurang Baik & 9 & 60,0 & 6 & 40,0 & 15 & 100 & \\
\hline
\end{tabular}

2. Hubungan Pemahaman Individu dengan Asupan Makanan Ibu Muda Menyusui

Berdasarkan Tabel 3, menunjukkan bahwa dari 21 responden dengan pemahaman individu baik, diketahui $9,5 \%$ konsumsi makanan ibu muda menyusui kurang, sedangkan 13 responden yang pemahaman individu kurang baik, diperoleh 46,2\% konsumsi ibu muda 
menyusui cukup. Berdasarkan uji Chi Square didapatkan nilai $p=0,003 \quad(p<0,05)$, dapat disumpulkan bahwa hipotesis (Ha) diterima, yang berarti ada pengaruh pemahaman individu terhadap konsumsi makanan ibu muda menyusui di Desa Sefoyan Kecamatan Simeulue Timur Kabupaten Simeulue.

Pemahaman individu sangat dipengaruhi oleh pengetahuan, dimana pengetahuan menjadi landasan penting untuk menentukan suatu tindakan. Pengetahuan, sikap dan perilaku seseorang akan kesehatan merupakan faktor yang menentukan dalam mengambil suatu keputusan. Orang yang berpengetahuan baik akan mengupayakan kemampuan menerapkan pengetahuannya didalam kehidupan seharihari. ${ }^{11}$

Pada saat menyusui sudah seharusnyalah ibu memiliki Pemahaman diri, bahwa banyaknya ASI yang akan dihasilkan seorang ibu tidak tergantung pada besarnya payudara, tetapi pada gizi ibu selama hamil dan menyusui, serta cara menyusui, dan dengan pengetahuan yang dimiliki ibu. ${ }^{7}$

Kondisi psikis dan juga makanan yang dikonsumsi oleh ibu juga dapat mempengaruhi produksi ASI. Kesulitan ibu menyusui tersebut menyebabkan ibu merasa cemas dan kawatir, menyebabkan ibu menjadi pesimis dengan jumlah ASI yang diperoleh dan menghambat produksi ASI. Apalagi bila gizi ibu kurang bisa menyebabkan kualitas ASI menjadi menurun. Dengan produksi ASI yang kurang tersebut, ibu yang memiliki pemahaman individu kurang mencari alternatif lain dengan memberikan susu formula pada bayinya yang menyebabkan intensitas isapan bayi menjadi berkurang karena bergantian dengan susu formula yang membuat ASI menjadi semakin sedikit yang keluar. ${ }^{12}$

Merujuk pada penelitian yang dilakukan di Karanganyar, diperoleh bahwa terdapat hubungan yang signifikan dengan $\mathrm{p}=0,001$ antara pengetahuan gizi dengan status gizi ibu menyusui di Posyandu Desa Gawanan Colomadu Karanganyar. ${ }^{13}$

Pemahaman diri ibu muda saat ini juga dipengaruhi oleh dua hal yang saling bertolakbelakang yang perlu dikaji lebih dalam, yaitu mudahnya akses media sosial bagi ibu muda dan kepercayaan dari orang tua yang mesti jalankan. Namun dalam realita, ibu muda menyusui sudah mulai memperhatikan pola makan, meskipun sebagian dari ibu tersebut bukan karena menyusui, melainkan menjaga kualitas makanan demi bentuk tubuh yang ideal.

\section{Hubungan Dukungan Keluarga dengan Asupan Makanan Ibu Muda Menyusui}

Hasil pada tabel 3, diketahui dari 27 responden yang memperoleh dukungan keluarga, maka sebanyak 14,8\% konsumsi makanan ibu muda menyusui kurang, dan dari 7 responden dengan dukungan keluarga kurang, maka 28,6\% konsumsi makanan ibu muda menyusui cukup. Hasil uji Chi Square didapatkan nilai $p=0,028 \quad(p<0,05)$, dapat disumpulkan bahwa hipotesis (Ha) diterima, yang berarti ada pengaruh dukungan keluarga terhadap konsumsi makanan ibu muda menyusui di Desa Sefoyan Kecamatan Simeulue Timur Kabupaten Simeulue.

Dukungan keluarga adalah dukungandukungan sosial yang dipandang oleh anggota keluarga sebagai sesuatu yang dapat diadakan untuk keluarga yang berupa memberikan dukungan. Dukungan keluarga memiliki fungsi dukungan informasi yaitu keluarga berfungsi sebagai pengumpul dan penyebar tentang suatu informasi baik yang diterima secara langsung dari istri, orang dekat dan tenaga kesehatan atau tidak langsung dari media cetak dan elektronik), dan dukungan penilaian dimana keluarga bertindak sebagai sebuah bimbingan umpan balik, membimbing dan menengahi pemecahan masalah dan sebagai sumber dan pengambil keputusan dalam ber-KB. 14

Kebutuhan dasar manusia merupakan sumber kekuatan yang mendorong kearah tujuan tertentu secara disadari maupun tidak disadari. Dorongan itu disebut dengan motivasi, motivasi bisa timbul dari dalam diri individu itu sendiri maupun yang datang dari lingkungan sekitarnya khususnya dukungan suami atau keluarga terdekat. ${ }^{15}$

Hasil penelitian ini sejelan dengan penelitian yang dilakukan di Purworejo, dimana terdapat hubungan dukungan keluarga dengan perilaku menyusui pada ibu yang mempunyai 
bayi 0-6 bulan di Puskesmas Kaligesing Kabupaten Purworejo tahun 2010, dengan nilai signifikansi $p: 0,032 .{ }^{16}$

Keluarga memberi pemahaman yang diketahui oleh keluarga berdasarkan turun temurun, yang hendaknya harus dijalankan, keluarga kurang memperhatikan ibu menyusui pada aspek pemenuhan gizi makanan, melainkan fokus pada cara-cara perawatan tradisional semata, dan dalam dukungan yang diberikan juga terbatas anjuran untuk makan nasi saja, tanpa memperhatikan keseimbangan gizi bagi ibu hamil

\section{Hubungan Sosial Budaya dengan Asupan Makanan Ibu Muda Menyusui}

Merujuk pada tabel 3, diketahui dari 19 responden dengan sosial budaya baik, maka diperoleh 15,8\% konsumsi makanan ibu muda menyusui kurang, sedangkan dari 15 responden dengan sosial budaya kurang baik, maka $60 \%$ konsumsi makanan ibu muda menyusui cukup. Hasil uji Chi Square didapatkan nilai $p=0,027$ $(p<0,05)$, dapat disumpulkan bahwa hipotesis (Ha) diterima, yang berarti ada pengaruh sosial budaya terhadap konsumsi makanan ibu muda menyusui di Desa Sefoyan Kecamatan Simeulue Timur Kabupaten Simeulue.

Lingkungan setempat/budaya adalah faktor yang berhubungan dengan nilai-nilai dan pandangan masyarakat yang lahir dari kebiasaan yang ada, dan pada akhirnya mendorong masyarakat untuk berperilaku sesuai dengan tuntutan budaya. Misalnya budaya yang baru berkembang sekarang ini adalah pandangan untuk tidak mengkonsumsi bahan makanan yang dipantang oleh budaya, karena dapat berdampak bagi kesehatan bayi. ${ }^{17}$

Pola konsumsi makan merupakan hasil budaya masyarakat yang bersangkutan dan mengalami perubahan terus menerus sesuai dengan kondisi lingkungan dan tingkat kemajuan budaya masyarakat. Pola konsumsi ini diajarkan dan bukan diturunkan secara herediter dari nenek moyang sampai generasi mendatang. ${ }^{18}$ Kebudayaan suatu masyarakat mempunyai kekuatan yang cukup besar untuk mempengaruhi seseorang dalam memilih dan mengolah pangan yang akan dikonsumsi. Kebudayaan menuntun orang dalam cara bertingkah laku dan memenuhi kebutuhan dasar biologisnya termasuk kebutuhan terhadap pangan. Pola makan yang seimbang, yaitu sesuai dengan kebutuhan disertai pemilihan bahan makanan yang tepat akan melahirkan status gizi yang baik. ${ }^{19}$ Pada banyak masyarakat, usia atau kondisi seseorang dapat dipakai sebagai alasan untuk melarang makanan-makanan tertentu. Sebagai contoh, permasalahan gizi pada ibu hamil di Indonesia tidak terlepas dari faktor budaya setempat. Hal ini disebabkan karena adanya kepercayaan-kepercayaan dan pantangan-pantangan terhadap beberapa makanan. ${ }^{20}$

Dilakukan penelitian kualitatif Daerah Jepara, dengan hasil bahwa selama kehamilan, biasanya si ibu akan melakukan berbagai upaya agar bayi dan ibunya sehat dan dapat bersalin dengan selamat, normal dan tidak cacat. Sebagian masyarakat masih berpantang makan makanan tertentu seperti udang atau kepiting dan buah nenas, walaupun menurut kesehatan pantangan makanan tertentu tidak dibenarkan apalagi kalau makanan tersebut bergizi. ${ }^{21}$

Masyarakat setempat secara umum masih memiliki kebiasaan atau kepercayaan yang membudaya terhadap makanan pada ibu hamil, seperti banyak pantangan dan tidak pengaruh makan dengan gizi seimbang terhadap kualitas ASI yang diberikan kepada bayi, sehingga masih ibu muda menyusui sebagian masih mengikuti sosial budaya yang ada di masyarakat tersebut.

\section{KESIMPULAN DAN SARAN}

Berdasarkan pelaksanaan dan uji hasil penelitian, maka diperoleh hasil bahwa, terdapat pengaruh pemahaman diri terhadap konsumsi makanan ibu muda menyusui. Terdapat pengaruh pemahaman individu terhadap konsumsi makanan ibu muda menyusui, terdapat pengaruh dukungan keluarga terhadap konsumsi makanan ibu muda menyusui dan terdapat pengaruh sosial budaya terhadap konsumsi makanan ibu muda menyusui di Desa Sefoyan Kecamatan Simeulue Timur Kabupaten Simeulue.

Diharapkan puskesmas dan kepada para bidan dan masyarakat agar dapat meningkatkan 
pemahaman individu ibu muda menyusui tentang kebutuhan nutrisi pada masa menyusui dengan berbagai cara, diantaranya penyuluhan dan pendampingan. Dan kepada ibu hamil diharapkan untuk memperhatikan asupan makanan dengan gizi seimbang pada saat masa kehamilan dan menyusui. Bagi Peneliti Lain, diharapakan penelitian ini dapat menjadi bahan dasar dalam melaksanakan penelitian lanjut dengan variabel yang lebih bervariasi dan mendalam.

\section{DAFTAR PUSTAKA}

1. Hidajati A. Mengapa Seorang Ibu Harus Menyusui. Yogyakarta: FlashBooks; 2012.

2. WHO. Report of the Expert Consultation of the Optimal Duration of Exclusive Breastfeeding. Geneva: World Health Organization; 2014.

3. AL-Rahmad AH, Miko A, Hadi A. Kajian stunting pada anak balita ditinjau dari pemberian ASI eksklusif, MP-ASI, status imunisasi dan karakteristik keluarga di Kota Banda Aceh. Jurnal Kesehatan Ilmiah Nasuwakes. 2013;6(2):169-184.

4. Al-Rahmad AH, Fadillah I. Perkembangan Psikomotorik Bayi 6-9 Bulan berdasarkan Pemberian ASI Eksklusif. Aceh Nutrition Journal. 2016;1(2):99-104.

5. Depkes RI. Undang-undang kesehatan nomor 36. 2009.

6. Trisnawati Y, Purwanti S, Retnowati M. Studi Deskriptif Pengetahuan dan Sikap Ibu Hamil tentang Gizi 1000 Hari Pertama Kehidupan di Puskesmas Sokaraja Kabupaten Banyumas. Jurnal Kebidanan. 2016;8(02):127-224.

7. Prasetyono DS. ASI Eksklusif Pengenalan, Praktik Dan Kemanfaatannya. Yogyakarta: Diva Press

8. Friedman M. Keperawatan Keluarga Teori Dan Praktik. Jakarta: Penerbit Buku Kedokteran (EGC); 2009.

9. Amran Y, Afni Amran VY. Gambaran pengetahuan ibu tentang menyusui dan dampaknya terhadap pemberian ASI eksklusif. Jurnal Kesehatan Reproduksi. 2012;3(1):52-61.

10. Permatasari E. Hubungan Asupan Gizi Dengan Produksi Asi Pada Ibu Yang Menyusui Bayi Umur 0-6 Bulan Di Puskesmas Sewon I Bantul Yogyakarta. Skripsi: Sekolah Tinggi Ilmu Kesehatan 'Aisyiyah Yogyakarta. 2015.

11. Unicef Indonesia. Ringkasan Kajian Gizi Ibu dan Anak. Retrieved January. October 2012:1-6.

12. Rahayu D. Faktor-Faktor yang Mempengaruhi Produksi ASI pada Ibu Nifas. 2012.

13. Wulansari MA. Hubungan Antara pengetahuan Gizi Dengan Status Gizi Ibu Menyusui Di Posyandu Desa Gawanan Colomadu Karanganyar. 2009.

14. Sukarni I, Wahyu P. Buku Ajar Keperawatan Maternitas. Yogyakarta: Nuha Medika; 2013.

15. Aprida S, Utami S, Hasneli Y. Efektifitas pendidikan kesehatan tentang imunisasi Tetanus toksoid (TT) terhadap pengetahuan ibu hamiltentang imunisasi TT. Jurnal Online Mahasiswa Program Studi Ilmu Keperawatan Universitas Riau. 2015;1(2):1-9.

16. Oktalina O, Muniroh L, Adiningsih S. Hubungan Dukungan Suami dan Dukungan Keluarga dengan Pemberian ASI Eksklusif Pada Ibu Anggota Kelompok Pendukung ASI (KP-ASI). Media Gizi Indonesia. 2016;10(1):64-70.

17. Nuzulia F. Hubungan antara dukungan keluarga dengan pemberian ASI eksklusif pada bayi di Desa Bebengan Kecamatan Boja Kabupaten Kendal. Jurnal Keperawatan Maternitas. 2013;1(1):1-8.

18. Mufidah NL. Pola konsumsi masyarakat perkotaan: studi deskriptif pemanfaatan foodcourt oleh keluarga. Jurnal Biokultur. 2012;2(2):157-178.

19. Sakti RE, Hadju V, Rochimiwati SN. Hubungan Pola Pemberian MP-ASI dengan Status Gizi Anak Usia 6-23 Bulan di Wilayah Pesisir Kecamatan Tallo Kota Makassar Tahun 2013. Jurnal MKMI. 2013;2(1):1-12. 
Pengaruh Individu, Dukungan Keluarga dan...

20. Khasanah N. Dampak Persepsi Budaya terhadap Kesehatan Reproduksi Ibu dan Anak di Indonesia. Jurnal Muwazah. 2011;3(1):487-492.

21. Suryawati C. Faktor sosial budaya dalam praktik perawatan kehamilan, persalinan, dan pasca persalinan (Studi di Kecamatan Bangsri Kabupaten Jepara). The Indonesian Journal of Health Promotion (Jurnal Promosi Kesehatan Indonesia). 2007;2(1):21-31. 